\title{
ÉCRIRE SA VIE: RELATOS DE UMA TRAJETÓRIA DE PESQUISA
}

\section{JOCELMA BOTO SILVA}

Universidade Estadual do Sudoeste da Bahia

RESUMO Em Écrire sa vie: du pacte au patrimoine autobiographique, Philippe Lejeune (2015) apresenta, de maneira didática, os principais resultados obtidos ao longo de mais de quarenta anos de estudos sobre os textos autobiográficos. É nesse pequeno volume que conhecemos um pouco da trajetória acadêmica que o transformou, pouco a pouco, em referência quando tratamos das formas de escrita de si. No Brasil, o conhecimento das obras desse pesquisador cresce à medida que avançam os estudos sobre a autobiografia, por isso, consideramos a temática desta resenha fundamental, já que, nela, propomos uma breve apresentação do objetivo de cada capítulo, ao mesmo tempo em que ressaltamos sua relevância teórica. Desse modo, acreditamos poder auxiliar a leitura de pesquisadores em solo nacional.

Palavras-chave: Autobiografia. Diário pessoal. Philippe Lejeune.

\section{LEJEUNE, Philippe. Écrire sa vie: du pacte \\ au patrimoine autobiographique. Paris: Mauconduit, 2015. 120 p.}

Em 120 páginas, Philippe Lejeune propõe ao leitor uma espécie de retrospectiva acadêmica de mais de 40 anos de trabalho. Pode parecer radical, mas é exatamente esse o percurso sugerido pelas quatro conferências e por uma entrevista, selecionadas para compor o pequeno livro. É, pois, uma versão sintética de suas maiores descobertas que aborda a transformação de um hobby em militância. Nesse volume, os leitores são convidados a descobrir os anseios desse pesquisador, os seus desafios e as conquistas que o tornaram, pouco a pouco, o "papa da autobiografia".
Respeitando o "estilo Lejeune de se escrever", em que encontramos sua própria figura multiplicada pelos papéis de pesquisador, professor, praticante de diários, crítico e outros (COELHO-PACE, 2012), a leitura é conduzida por uma espécie de "pesquisador autobiógrafo" que se permite dizer "eu", pois já não fala da autobiografia como um objeto distante, mas como parte de si mesmo e de suas vivências. Assim, nesse tom confessional, seus textos tentam, também, aproximarnos desse universo simples e místico que é a escrita de si. 
Em Itinéraires d'une recherche, acompanhamos a gênese dos estudos autobiográficos através dos primeiros passos de Lejeune para a invenção de uma nova arte. É nesse capítulo que conhecemos sua primeira paixão, as autobiografias de grandes homens, como Rousseau, Sartre e Leiris, e sua explanação até os textos escritos por pessoas comuns. Vimos nascer também o conceito de pacto autobiográfico e assistimos às suas revisitações. Testemunhamos, ainda, as razões que culminaram na criação da Association Pour l'Autobiographie et le Patrimoine Autobiographique ${ }^{1}$ - APA, e na construção de um patrimônio autobiográfico no território francês. Por fim, somos surpreendidos com o Lejeune diarista, ao relatar que, desde a adolescência, já se via afetado por seu objeto.

"Nous lisons 'en sympathie'2"(2015, p. 54), nos confidencia Lejeune, no segundo capítulo, ao comentar as experiências de leitura às quais se condicionam os membros da APA. Divididas em grupos de "apaixonados", as reuniões acontecem mensalmente, seguindo os princípios propostos desde 2005 , a fim de que haja certa coerência nesse trabalho, e seguem o mesmo ritual, que as trarão, nas palavras de Lejeune "le même goût, la même vertu nutritive, la même convivialité, le même partage ${ }^{3 "}$ (2015, p. 49).

Em um capítulo sentimental, o autor narra o ritual: menciona o espírito de curiosidade que o motiva há tantos anos; conta como se dá a distribuição dos textos para leitura, momento que é comparado a um "leilão"; esclarece como acontece a socialização dos escritos e a produção do "écho", que é direcionado ao autobiógrafo e publicado no Garde-mémoire, uma espécie de banco de dados de leituras. É

1 Associação pela Autobiografia e o Patrimônio Autobiográfico (tradução nossa).

2 “Nós lemos ‘em simpatia”" (tradução nossa).

3 "O mesmo gosto, a mesma virtude nutritiva, a mesma convivência, a mesma partilha" (tradução nossa). nessa etapa do livro que conhecemos os bastidores de um trabalho, cujo objetivo não é o de proferir críticas acerca do texto ou sobre as vivências de seu autor, mas que apresenta, como foco, a garantia da leitura dos escritos que foram depositados na associação.

$\mathrm{Na}$ terceira conferência, somos convidados a acompanhar os bastidores de uma obra ou, melhor dizendo, os caminhos percorridos por Lejeune para "comprendre comment elle a était fait" ${ }^{\prime 4}$ (2015, p. 67). Nosso pesquisador, interessado em desvendar como André Pézard transformou suas memórias diarísticas em testemunhos de guerra através do livro Nous autres à Vauquois, mostra-nos mais uma faceta de detetive, ao seguir as pistas escritas deixadas por seu primo distante. Lejeune relembra as longas horas de paciência e de compromisso em que buscou, leu, fotografou, transcreveu e comparou os "rascunhos" com o "produto final". Como resultado, destaca que, "os rascunhos da obra" são mais abrangentes já que pode observar "autour des écritures de la guerre, celles de toute une vie, avant e après"5 (2015, p. 72). Na edição, por sua vez, muitas informações foram suprimidas, de modo que Lejeune sinalizou que "le texte du livre obéit à d'autres lois", 6 cujas regras eram "la discontinuité, l'ellipse"7 (2015, p. 75).

$\mathrm{Na}$ única entrevista do volume, o pesquisador responde a Brigitte Diaz questões relacionadas às origens do diário pessoal, que é o nome e o tema de seu mais recente livro que, naquele momento, estava em fase de produção. Nela, são abordados temas como o aspecto pessoal do diário, suas funções, suas variedades de escrita, sua definição, sua evolução e a permanência em solo francês, enfim, seus aspectos mais "intimos". Nesse

4 "Compreender como ela foi feita" (tradução nossa).

5 "Em meio aos escritos de uma guerra, aqueles de uma vida, antes e depois" (tradução nossa).

6 "Os textos do livro obedecem a outras leis" (tradução nossa).

7 "A descontinuidade, a elipse" (tradução nossa). 
momento, lidamos, mais uma vez, com um militante que apresenta e defende uma prática que, em suas palavras, "on ne connaît quasiment rien par rapport à ce qui a existé"8 (2015, p. 81).

Por fim, em À L'ère du numérique, Lejeune trata a autobiografia a partir dos novos meios de comunicação, o computador e a Internet, e expõe algumas considerações acerca dos textos manuscritos e daqueles que acontecem sobre a "cher écran". ${ }^{9}$ Para o pesquisador, o grande diferencial do diário on-line está na "sociabilidade intima", que permite, entre tantas outras possibilidades, a interação entre autor e leitor, e traz, como resultado, "une nouvelle construction sociale de l'indentité et une nouvelle construction du temps"10 (2015, p. 112). Quanto à autobiografia, Lejeune destaca que sua versão on-line ainda é bastante tímida se a comparamos com o diário, pois, devido a sua extensão textual, existem poucos cyberleitores. Mais tímida ainda é a evolução da correspondência pessoal. Para Lejeune, o correio eletrônico pode exemplificar essa nova faceta, mas, o papel ainda é mais utilizado como aspecto pessoal por aqueles que optam por escrever cartas.

Na leitura de Écrire sa vie, conhecemos o percurso pessoal e acadêmico da invenção de uma arte novíssima; seguimos os passos de um teórico que reconheceu e reconhece seus próprios equívocos e que ratifica suas descobertas; lidamos com um pesquisador intimamente afetado por seu objeto e que é, ao mesmo tempo, sua teoria e sua prática; apreciamos, por fim, um homem militante que defende a importância cultural, histórica, social e acadêmica da autobiografia.

\section{Referência}

COELHO-PACE, A. A. B. Lendo e escrevendo sobre

o Pacto Autobiográfico de Philippe Lejeune. 2012.

177 f. Dissertação (Mestrado em Língua e Literatura Francesa) - Programa de Estudos Linguísticos, Literários e Tradutológicos em Francês, Universidade de São Paulo, São Paulo, 2012. Disponível em: <www. teses.usp.br/.../2012 AnaAmeliaBarrosCoelhoPace vCorr.pdf>. Acesso em: 02 abr. 2015.

Recebido em: 07.08.2017

Aprovado em: 30.10.2017

Jocelma Boto Silva é Mestra em Linguística pelo Programa de Pós-Graduação em Linguística pela Universidade Estadual do Sudoeste da Bahia - Uesb. Atua na área de Linguística Textual, com ênfase nos estudos sobre os gêneros autobiográficos. e-mail: jocelmaboto@gmail.com

Rua Isaias Matos, SN, Bairro Tangará, Piatã - Bahia. CEP 46765-000. Telefone: (77) 99103-8371

8 "Nós não conhecemos praticamente nada em comparação com o que existia" (tradução nossa).

9 "Querida tela" (tradução nossa).

10 "Uma nova construção social de identidade e uma nova construção do tempo" (tradução nossa). 